\title{
ANALISIS PENGELOLAAN ANGGARAN PENDAPATAN DAN BELANJA DESA BEBETIN KECAMATAN SAWAN
}

\author{
Masrudiyanto, Erna Kartika, Nyoman Oky Novianti Sari, Nyoman Depi \\ Jayantini \\ Jurusan Akuntansi, Universitas Pendidikan Ganesha, Singaraja, Bali, Indonesia
}

\begin{abstract}
Abstrak
Penelitian ini bertujuan untuk mengetahui darimana sumber dana dalam kegiatan operasional desa, bagaimana pengelolaan anggaran untuk membiayai belanja desa Bebetin pada tahun 2018, apakah dalam pengelolaan keuangan mengalami surplus atau defisit. Berdasarkan hasil penelitian diketahui bahwa jumlah pendapatan Desa Bebetin adalah sejumlah Rp. 2.721.115.000 dan jumlah biaya yang dikeluarkan untuk membiayai kegiatan operasional dan belanja Desa Bebetin sebesar Rp. 2.721.115.000 Sehingga dari jumlah tersebut dapat diketahui selisih antara pendapatan Desa Bebetin dengan biaya yang dikeluarkan untuk membiayai kegiatan operasional dan Belanja Desa bebetin Sebesar Rp.51.546.985,09. Dari selisih jumlah pendapatan dan jumlah pengeluaran untuk kegiatan operasional dan belanja desa dapat diketahui bahwa biaya yang dikeluarkan untuk membiayai kegiatan operasional dan Belanja Desa Bebetin lebih besar dari Pendapatan yang diperoleh Desa Bebetin sehingga dalam pengelolaan keuangan Desa Bebetin Tahun 2018 dikatakan mengalami defisit.
\end{abstract}

Kata kunci: Anggaran, Belanja Desa, Operasional

\begin{abstract}
This study aims to find out where the source of funds in village operational activities, how to manage the budget to finance Bebetin village spending in 2018, whether in financial management has a surplus or deficit. Based on the results of the study note that the total income of the village of Bebetin is Rp. 2,721,115,000 and the total costs incurred to finance the operational and expenditure activities of the village of Bebetin amounted to Rp. 2,721,115,000 So that from this amount it can be seen the difference between the revenue of the Bebetin Village and the costs incurred to finance operational activities and the village expenditure of the bulletin in the amount of Rp.51,546,985.09. From the difference in the amount of income and expenditure for village operational and expenditure activities, it can be seen that the costs incurred to finance operational activities and Bebetin Village Expenditure are greater than the income obtained by Bebetin Village so that in the financial management of Bebetin Village in 2018 it is said to have a deficit.
\end{abstract}

Keywords : Budget, Village Expenditure, Operations

\section{Pendahuluan}

Pemahaman mengenai pengelolaan dana desa di desa menjadi aspek penting dan mendasar yang harus dimiliki para pemangku kepentingan di level pemerintahdesa (pemdes), khususnya perangkat desa dalam mewujudkan transparansi dana kuntabilitas keuangan desa. Prinsipdasarpengelolaankeuangandesa, dimulai dari tahap perencanaan sampai dengan pelaporan dan pertanggungjawaban keuangan desa serta tugas dan tanggungjawab para pejabat pengelola. Berdasarkan Pertauran Menteri Dalam NegeriNomor 113 Tahun 2014 tentang Pengelolaan Keuangan Desa, pengelolaan dana desa itu harus dilakukan secara transparan, akuntabel, partisipatif, tertib, dan disiplin anggaran. Jangka waktu pengelolaan dana desa dimulai dari 1 Januari hingga 31 Desembertahunberjalan yang dituangkan dalam Anggaran Pendapatan dan BelanjaDesa (APBDesa).

APBDesa terdiri atas pendapatan desa, belanja desa, dan pembiayaan desa. Perencanaan dalam pengelolaan keuangan desa itu disusun sekretaris desa (sekdes). Dalam mekanisme perencanaan dalam pengelolaan keuangan desa, sekdes terlebih dulu menyusun Rancangan Peraturan Desa (Raperdes) APBDesa. Kemudian, kepala desa (kades) menyampaikan Raperdes APBDesa kepada Badan Permusyawaratan Desa 
(BPD) untuk dibahas dan disepakati bersama.Raperdes APBDesa yang telah disepakati, disampaikan kepada bupati atauwalikota melalui camat. Bupati atau walikota lalu menetapkan hasil evaluasi Raperdes APBDesa. Camat juga dapa tmengevaluasi Raperdes APBDesa berdasarkan pendelegasian wewenang dari bupati atau walikota.

Peraturan Desa berlaku bila bupati atau walikota tidak memberikan hasil evaluasi. Bila mereka menyatakan hasil evaluasi Raperdes APBDesa tidak sesuai dengan kepentingan umum dan peraturan perundang-undangan, Kades harus melakukan penyempurnaan.Bupati atau walikota membatalkan Perdes bila kades tidak menindaklanjuti hasil evaluasi. Pembatalan Peraturan Desa sekaligus menyatakan berlakunya pagu APBDesa tahun anggaran sebelumnya.Kades memberhentikan pelaksanaan Perdesdan selanjutnya Kadesbersama BPD mencabut Perdes yang dimaksud. Pengelolaan keuangan yang di lakukan di setiap desa hendaknya sama, karena sudah ada peraturan yang mengatur akan hal tersebut.

Pada PERMENDAGRI 113/2014 yang mendefinisikan keuangan desa seperti "Keuangan Desa adalah semua hak dan kewajiban Desa yang dapat dinilai dengan uang serta segala sesuatu berupa uang dan barang yang berhubungan dengan pelaksanaan hak dan kewajiban Desa". Pada PERMENDAGRI 20/2018 menyatakan "Keuangan Desa adalah semua hak dan kewajiban Desa yang dapat dinilai dengan uang serta segala sesuatu berupa uang dan barang yang berhubungan dengan pelaksanaan hak dan kewajiban Desa". Terdapat azas-azas pengelolaan keuangan desa yang mendasari dalam pengelolaan keuangan, PERMENDAGRI 113/2014; Keuangan desa dikelola berdasarkan asas-asas transparan, akuntabel, partisipatif serta dilakukan dengan tertib dan disiplin anggaran; Pengelolaan keuangan desa, dikelola dalam masa 1 (satu) tahun anggaran yakni mulaitanggal 1 Januari sampai dengan tanggal 31 Desember. Dan PERMENDAGRI 20/2018; Keuangan Desa dikelola berdasarkan asas-asas transparan, akuntabel, partisipatif serta dilakukan dengan tertib dan disiplin anggaran.; APB Desa merupakan dasar pengelolaan keuangan Desa dalam masa 1 (satu) tahun anggaran mulai tanggal 1 Januari sampai dengan tanggal 31 Desember.

Berdasarkan masalah diatas adapun rumusan masalah dilakukan yaitu darimana sumber dana untuk mendanai kegiatan operasional desa, bagaimanapengelolaan anggaran untuk membiayai belanja desa Bebetin pada tahun 2018, apakah dalam pengelolaan keuangan mengalami surplus atau defisit.

\section{Hasil dan Pembahasan}

Penelitian ini dilakukan, di Desa Bebetin , kecamatan sawan, kabupaten buleleng. Desa Bebetin, merupakan salah satu desa dari pemerintahan kecamatan sawan kabupaten buleleng, yang mempunyai potensi yang cukup baik dalam pembangunan karena desa Bebetin berada tidak jauh dari pusat kecamatan. Penduduk desa Bebetin, didominasi masyarakat yang mempunyai mata pencarian sebagai petani dan wirausaha. Pada tahun 2018, desa Bebetin memiliki pendapatan dengan jumlah Rp.2.721.115.000 yang digunakan untuk kegiatan operasional.

Dari hasil penelitian yang kelompok saya lakukan, diketahui bahwa pendapatan desa bebetin per tahun 2018 bersumber dari:

1 Pendapatan asli desa

2 Bagian dari hasil pajak dan retribusi daerah kabupaten/kota

3 Alokasi dana desa

4 Bantuan keuangan

5 Pendapatan lain-lain adalah:

Sedangkan pengeluaran untuk kegiatan oprasional dan belanja desa Bebetin

1 Belanja di bidang penyelenggaraan pemerintah desa

2 Belanja di bidang pembangunan desa

3 Belanja di bidang pembinaan kemasyarakatan

4 Belanja di bidang pemberdayaan masyarakat

5 Belanja di bidang tak terduga 
Dari Pendapatan dan Belanja Desa Bebetin, sudah terealisasikan dengan baik. Namun, masih terdapat kekurangan dalam pengelolaannya Sehingga dalam pengelolaan keuangannya mengalami defisit.

Informasi dari Bapak Kadek Mei selaku Sekretaris Kantor Kepala Desa, apabila terdapat selisih lebih dari realisasi pendapatan dan belanja desa bebetin dengan apa yang dianggarkan, maka selisih lebihnya akan digunakan untuk pendanaan di kegiatan dana desa dan alokasi dana desa (ADD). Dan apabila terjadi selisih kurang, maka pihak kantor desa akan memprioritaskan pengalokasian dana untuk kegiatan-kegiatan di bidang pembangunan desa dan di bidang pemberdayaan masyarakat desa.

\section{Sumber Dana Untuk Mendanai Kegiatan Operasional Desa}

Pembangunan yang dilakukan pemerintah desa sesuai dengan hasil musyawarah sehingga pembangunan bisa sesuai dengan apa yang direncanakan. Sumber pendapatan dana dari desa Bebetin di bagi menjadi pendapatan asli desa, pendapatan transfer, dan pendapatan lain-lain. Berikut ini adalah pendapatan desa Bebetin pada tahun 2018:

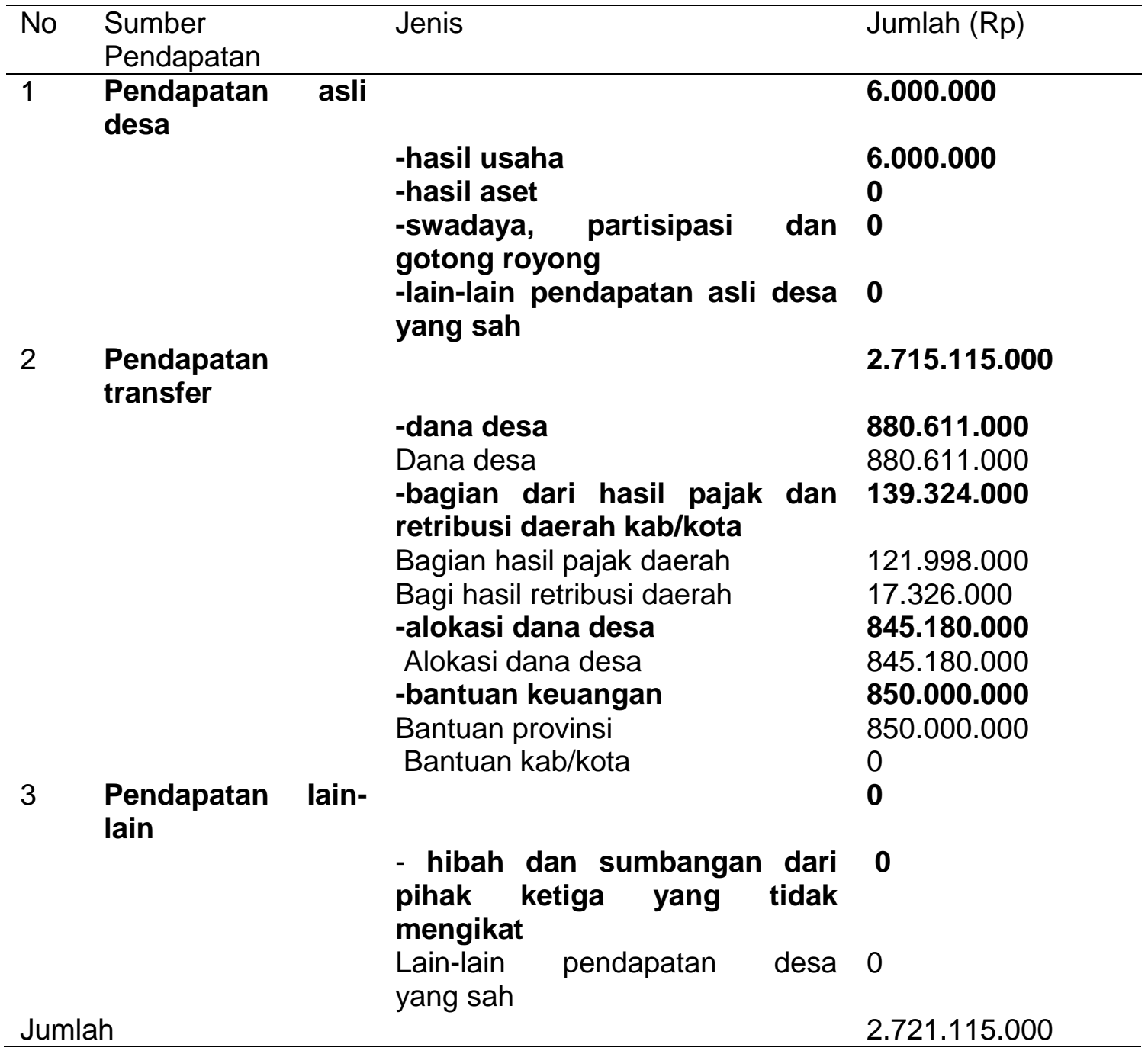

Berdasarkan tabel, 1.1 dapat diketahui bahwa tahun 2018 total pendapatan desa Bebetin sebesar Rp. 2.721.115.000. Dengan rincian sebagai berikut:

Pendapatan Asli Desa

1 Hasil usaha yang pada tahun 2018 sebesar Rp. 6.000 .000

2 Hasil Aset yang pada tahun 2018 sebesar Rp. 6.000.000

3 Swadaya, partisipasi dan gotongroyong yang pada tahun 2018 sebasar Rp.0 
4 Lin-lain pendapatan asli daerah yang sah yang pada tahun 2018 sebasar Rp.0 Pendapatan Transfer

1. Dana desa pada tahun 2018 sebesar Rp. 880.611 .000

2. Bagian dari hasil pajak dan retribusi daerah kabupaten/kota pada tahun 2018 sebesar Rp. 139.324.000

- Bagi hasil pajak daerah pada tahun 2018 sebesar Rp. 121.998 .000

- Bagi hasil retribusi daerah pada tahun 2018 sebesar Rp. 17.326.000

3. Aokasi dana desa yang dianggarkan sebesar Rp. 845. 180.000

4. Bantuan keuangan pada tahun 2018 sebesar Rp.850.000.000

- Bantuan provinsi pada tahun 2018 sebesar Rp. 850.000.000

- Bantuan kabupaten/kota pada tahun 2018 Rp.0

Pendapatan lain-lain

1. Hibah dan Sumbangan dari pihak ketiga yang tidak mengikat pada tahun 2018 sebesar Rp. 0

2. Lain-lain pendapatan desa yang sah pada tahun 2018 sebesar Rp.0

\section{Pengelolaan Keuangan untuk membiayai belanja desa Bebetin pada tahun 2018}

Pada tahun 2018, Desa Bebetin menerima pendapatan sebesar Rp.2.721.115.000 yang digunakan untuk membiayai kegiatan operasional dan belanja Desa Bebetin. Pembiayaan untuk kegiatan operasional dan belanja terdiri dari 5 bidang yaitu, bidang penyelenggaraan pemerintahan desa, bidang pembangunan desa, bidang pembinaan kemasyarakatan, bidang pemberdayaan masyarakat, dan bidang tak terduga.Dari masingmasing bidang tersebut, memiliki jumlah pengeluaran yang berbeda, yang dapat dilihat pada tabel 1.2

\begin{tabular}{lll}
\hline No & Bidang & Jumlah Pengeluaran (Rp) \\
\hline 1 & bidang penyelenggaraan & 784.827 .056 \\
& pemerintahan desa & \\
2 & bidang pembangunan desa & 1.685 .200 .000 \\
3 & bidang pembinaan kemasyarakatan & 196.138 .000 \\
4 & bidang pemberdayaan masyarakat & 103.472 .000 \\
5 & bidang tak terduga & $3.024 .929,09$ \\
& Jumlah & $2.772 .661 .985,09$ \\
\hline
\end{tabular}

\section{Pengelolaan Keuangan Desa Bebetin}

Berdasarkan hasil penelitian diketahui bahwa jumlah pendapatan Desa Bebetin adalah sejumlah Rp. 2.721.115.000 dan jumlah biaya yang dikeluarkan untuk membiayai kegiatan operasional dan belanja Desa Beetin sebesar Rp. 2.721.115.000 Sehingga dari jumlah tersebut dapat diketahui selisih antara pendapatan Desa Bebetin dengan biaya yang dikeluarkan untuk membiayai kegiatan operasional dan Belanja Desa bebetin Sebesar Rp.51.546.985,09. Jumlah tersebut diperoleh dari Rp.2.721.115.000 - Rp.2.721.115.000 = Rp. 51.546.985,09. Dari selisih jumlah pendapatan dan jumlah pengeluaran untuk kegiatan operasional dan belanja desa dapat diketahui bahwa biaya yang dikeluarkan untuk membiayai kegiatan operasional dan Belanja Desa Bebetin lebih besar dari Pendapatan yang diperoleh Desa Bebetin sehingga dalam pengelolaan keuangan Desa Bebetin Tahun 2018 dikatakan mengalami defisit.

Informasi dari Bapak Kadek Mei selaku Sekretaris Kantor Kepala Desa, apabila terdapat selisih lebih dari realisasi pendapatan dan belanja desa bebetin dengan apa yang dianggarkan, maka selisih lebihnya akan digunakan untuk pendanaan di kegiatan dana desa dan alokasi dana desa (ADD). Dan apabila terjadi selisih kurang, maka pihak kantor desa akan memprioritaskan pengalokasian dana untuk kegiatan-kegiatan di bidang pembangunan desa dan di bidang pemberdayaan masyarakat desa. 


\section{Simpulan dan Saran Simpulan}

Berdasarkan hasil peneleitian dapat diketahui bahwa tahun 2018 total pendapatan desa Bebetin sebesar Rp. 2.721.115.000. Dengan rincian sebagai berikut:

Pendapatan Asli Desa

1. Hasil usaha yang pada tahun 2018 sebesar Rp. 6.000.000

2. Hasil Aset yang pada tahun 2018 sebesar Rp. 6.000.000

3. Swadaya, partisipasi dan gotongroyong yang pada tahun 2018 sebasar Rp.0

4. Lin-lain pendapatan asli daerah yang sah yang pada tahun 2018 sebasar Rp.0

Pendapatan Transfer

1. Dana desa pada tahun 2018 sebesar Rp. 880.611 .000

2. Bagian dari hasil pajak dan retribusi daerah kabupaten/kota pada tahun 2018 sebesar Rp. 139.324.000

- Bagi hasil pajak daerah pada tahun 2018 sebesar Rp. 121.998.000

- Bagi hasil retribusi daerah pada tahun 2018 sebesar Rp. 17.326.000

3. Aokasi dana desa yang dianggarkan sebesar Rp. 845. 180.000

4. Bantuan keuangan pada tahun 2018 sebesar Rp. 850.000.000

- Bantuan provinsi pada tahun 2018 sebesar Rp. 850.000.000

- Bantuan kabupaten/kota pada tahun 2018 Rp.0

Pendapatan lain-lain

1. Hibah dan Sumbangan dari pihak ketiga yang tidak mengikat pada tahun 2018 sebesar Rp. 0

2. Lain-lain pendapatan desa yang sah pada tahun 2018 sebesar Rp.0

Pada tahun 2018, Desa Bebetin menerima pendapatan sebesar Rp. 2.721.115.000 yang digunakan untuk membiayai kegiatan operasional dan belanja Desa Bebetin. Pembiayaan untuk kegiatan operasional dan belanja terdiri dari 5 bidang yaitu, bidang penyelenggaraan pemerintahan desa jumlah pengeluaran sebesar Rp.784.827.056, bidang pembangunan desa jumlah pengeluaran sebesar Rp.1.685.200.000, bidang pembinaan kemasyarakatan jumlah pengeluaran sebesar Rp.196.138.000, bidang pemberdayaan masyarakat jumlah pengeluaran sebesar Rp.103.472.000, dan bidang tak terduga jumlah pengeluaran sebesar Rp.3.024.929,09.

Berdasarkan hasil penelitian diketahui bahwa jumlah pendapatan Desa Bebetin adalah sejumlah Rp. 2.721.115.000 dan jumlah biaya yang dikeluarkan untuk membiayai kegiatan operasional dan belanja Desa Beetin sebesar Rp. 2.721.115.000 Sehingga dari jumlah tersebut dapat diketahui selisih antara pendapatan Desa Bebetin dengan biaya yang dikeluarkan untuk membiayai kegiatan operasional dan Belanja Desa bebetin Sebesar Rp.51.546.985,09. Dari selisih jumlah pendapatan dan jumlah pengeluaran untuk kegiatan operasional dan belanja desa dapat diketahui bahwa biaya yang dikeluarkan untuk membiayai kegiatan operasional dan Belanja Desa Bebetin lebih besar dari Pendapatan yang diperoleh Desa Bebetin sehingga dalam pengelolaan keuangan Desa Bebetin Tahun 2018 dikatakan mengalami defisit.

Informasi dari Bapak Kadek Mei selaku Sekretaris Kantor Kepala Desa, apabila terdapat selisih lebih dari realisasi pendapatan dan belanja desa bebetin dengan apa yang dianggarkan, maka selisih lebihnya akan digunakan untuk pendanaan di kegiatan dana desa dan alokasi dana desa (ADD). Dan apabila terjadi selisih kurang, maka pihak kantor desa akan memprioritaskan pengalokasian dana untuk kegiatan-kegiatan di bidang pembangunan desa dan di bidang pemberdayaan masyarakat desa.

\section{DAFTAR PUSTAKA}

Anonim.23 desember 2015“teknik pengelolaan keuangan desa di kutip dari "www.berdesa.com/teknik-pengelolaan-keuangan-desa 
Sumara.ayi. "keuangan desa"5 agustus 2018 di kutip dari www.keuangandesa.info/2018/05/pengelolaan-keuangan-desa-permendagri-202018.html

Tempo.com."pemdes harus memahami mekanisme pengelolaan dana desa"18 juli 2018. di kutip dari https://nasional.tempo.co/read/1108063/pemdes-harus-memahamimekanisme-pengelolaan-dana-desa

Anonim. "Pengelolaan keuangan desa". 4 juni 2015. di kutip darihttps://nasional.tempo.co/read/1108063/pemdes-harus-memahami-mekanismepengelolaan-dana-desa

Agus.puji. "pengelolaan keuangan desa:sistem dan prosedur pelaksanaan keuangan desa" 2 februari 2015. di kutip darihttps://nasional.tempo.co/read/1108063/pemdes-harusmemahami-mekanisme-pengelolaan-dana-desa 